\title{
Model Madrasah Sains Integratif: Menakar Konsep dan Strategi Pembelajaran Berbasis Relasi Sains dan Agama
}

\author{
Anggun Zuhaida, Nur Hasanah, Wulan Izzatul Himmah \\ IAIN Salatiga, Indonesia \\ anggunzub@iainsalatiga.ac.id,Nurbasanab201157@yaboo.com, \\ Wulan_himmab@iainsalatiga.ac.id
}

\begin{abstract}
Relations between science and religion are issues that have been developing for a long time, especially in Indonesia. Science as a pillar of human civilization cannot be separated from the attention of religions in the world. In Indonesia, efforts to establish the color of religion in its main education about scientific integration have been a concern in several Islamic universities. The purpose of this study was to find out the concepts and strategies of science and religion relations in learning in madrasas. This research method uses descriptive methods. The researcher measured the relation between science and religion by adapting to the approach developed by Ian G. Barbour which was divided into four: conflict; independence; dialog; and integration. The researcher found that the MTSN Kota Salatiga in the concept component was at the level of integration, but the strategy component was still at the level of dialogue. Whereas in the MTs NU Kota Salatiga it is known that the concept components and strategies are still at the level of dialogue.
\end{abstract}

Keywords: Science, Religion, Learning

\begin{abstract}
Abstrak
Relasi ilmu dan agama adalah isu yang sudah cukup lama berkembang, utamanya di Indonesia. Ilmu sebagai pilarperadaban manusia, tidak dapat lepas dari perhatian agama-agama di dunia. Di Indonesia, upaya tentang adanya warna agama dalam pendidikan utamanya tentang integrasi keilmuan telab menjadiperhatian di beberapa perguruan tinggi islam. Tujuan dalam penelitian ini adalah, ingin mengetabui konsep dan strategi relasi sains dan agama dalam pembelajaran di madrasah. Metode penelitian ini menggunakan metode deskriptif. Peneliti menakar relasi sains dan agama tersebut dengan mengadaptasi dari pendekatan yang dikembangkan oleb Ian G. Barbour yang terbagi atas empat: konflik; independensi; dialog; dan integrasi. Peneliti menemukan bahwa pada MTsN Kota Salatiga dalam komponen konsep sudah pada tataran integrasi, namun pada komponen strategi masih pada tataran dialog. Sedangkan pada MTS NU Kota Salatiga diketahui bahwa pada komponen konsep, dan strategi masih pada tataran dialog.
\end{abstract}

Kata kunci: Sains, Agama, Pembelajaran

Permalink/DOI: http://dx.doi.org/10.18326/infsl3v12i2.435-456 


\section{Pendahuluan}

Kurikulum 2013 mengusung adanya keseimbangan antara sikap, keterampilan, dan pengetahuan untuk membangun soft skills dan hard skills. Salah satu karakteristik Kurikulum 2013 adanya keseimbangan antara sikap, keterampilan, dan pengetahuan untuk membangun soft skills dan hard skills peserta didik dari mulai jenjang SD, SMP, SMA/ SMK, dan PT seperti yang diungkapkan Marzano (1985) dan Bruner (1960). Pada jenjang SD ranah attitude harus lebih banyak atau lebih dominan dikenalkan, diajarkan dan atau dicontohkan pada anak, kemudian diikuti ranah skill, dan ranah knowledge lebih sedikit diajarkan pada anak. Hal ini berbanding terbalik dengan membangun soft skills dan hard skills pada jenjang PT. Di PT ranah knowledge lebih dominan diajarkan dibandingkan ranah skills dan attitude (Fiteriani, 2014).

Dalam kurikulum 2013 untuk jenjang SD, SMP, SMA, dan PT memadukan lintasan taksonomi sikap (attitude) dari Krathwohl, keterampilan (skill) dari Dyers, dan Pengetahuan (knowledge) dari Bloom dengan revisi oleh Anderson. Taksonomi sikap (attitude) dari Krathwohl meliputi: accepting, responding, valuing, organizing/ internalizing, dan characterizing/actualizing. Taksonomi keterampilan (skill) dari Dyers meliputi: observing, questioning, experimenting, associating, dan communicating. Taksonomi pengetahuan (knowledge) dari Bloom, revisi Anderson meliputi: knowing/ remembering, understanding, appllying, analyzing, evaluating, dan creating (Kemendikbud, 2014).

Ilmu menurut kamus besar bahasa Indonesia (Hamzah, 2015) diartikan sebagai pengetahuan tentang suatu bidang yang disusun secara bersistem menurut metode-metode tertentu, yang dapat digunakan untuk menerangkan gejala-gejala tertentu dibidang pengetahuan. Secara etimologis pengertian ilmu adalah sebagian pengetahuan yang bersifat koheren, empiris, sistematis, dapat diukur dan dibuktikan. Berbeda dengan iman, yaitu pengetahuan yang didasarkan atas keyakinan kepada yang gaib dan penghayatan serta pengalamapribadi. Sedangkan pengetahuan adalah suatu fenomena yang ditangkap oleh panca indera dandisusun sebagai 
sebuah informasi. Ilmu agama dan sains selama ini senantiasa diperdebatkan dan dipertentangkan.

Sains adalah pengetahuan yang sistematis. Sains adalah suatu eksplorasi ke alam materi berdasarkan observasi dan mencari hubungan-hubungan alamiah yang teratur mengenai fenomena yang diamati serta bersifat mampu menguji diri sendiri. Sains bertumpu pada objektivitas yang dapat diuji ulang dan merupakan kontribusi semua ilmuwan di muka bumi tanpa pandang bangsa dan negara (Purwanto, 2012).

Pada prinsipnya sains dibangun di atas tiga dasar utama, yaitu fondasi atau pilar ontologi, aksiologi, dan epistimologi. Pilar ontologi terkait dengan subjek atau realitas apa yang (dianggap) ada dan dapat dikaji atau diketahui. Aksiologi terkait dengan tujuan suatu ilmu pengetahuan, untuk apa. Sedangkan epistemologi berhubungan dengan cara dan sumber suatu pengetahuan, dengan apa atau bagaimana suatu pengetahuan dapat diperoleh. Ketiga pilar inilah yang menentukan karakteristik suatu sains, yang membedakan satu sains dengan sains yang lain (Purwanto, 2012)..

Beberapa tantangan untuk dapat menggali relasi sains dan agama dalam dunia pendidikan. Diantaramya adalah: 1) pengetahuan dan kemampuan dari seorang guru untuk dapat menghubungkan sains dan agama dalam pelaksanaan pembelajaran, 2) kebijakan dari lembaga bahkan pemerintahan tentang adanya relasi sains dan agama, dan 3) tuntutan kurikulum dan output dari peserta didik untuk menghasilkan siswa yang siap untuk menghadapi tantangan masa depan (Hasanah \& Zuhaida, 2018).

Dari beberapa hal di atas menjadikan penulis mencoba melihat relasi sains dan agama dalam pembelajaran yang akan dipaparkan berdasarkan pandangan hubungan sains dan agama menurut Ian G. Barbour. Barbour memaparkan empat pandangan tentang hubungan sains dengan agama, yaitu konflik, independensi, dialog, dan integrasi (Barbour 2002). Keempat hubungan tersebut nantinya akan dilihat dalam segi konsep dan strategi pelaksanaan pembelajaran di kelas. Sehingga nantinya dapat diketahui konsep dan strategi relasi sains dan agama dalam pembelajaran di madrasah. 


\section{Metode Penelitian}

Penelitian ini merupakan bentuk penelitian deskriptif, karena bertujuan untuk membuat deskripsi secara sistematis, faktual dan akurat mengenai fakta-fakta, dan sifat-sifat populasi (Suryana, 2010). Pendekatan yang digunakan dalam penelitian ini adalah menggunakan pendekatan campuran dimana menggunakan pendekatan kualitatif.

Metode kualitatif digunakan untuk deskripsi hasil validasi ahli, hasil angket, wawancara dan observasi tentang relasi sains dan agama dalam pembelajaran. Desain penelitian dimulai dari perencanaan, pengembangan instrumen, pengumpulan data, analisis data, dan uraian temuan. Pada tahap perencanaan, peneliti mengidentifikasi informasi yang dibutuhkan dan darimana informasi tersebut akan diperoleh.

Langkah pembuatan instrumen dilakukan dengan: 1) menentukan subjek penelitian: subjek penelitian ini menggunakan sampel penelitian. Sampel dalam penelitian ini diambil dengan teknik Purposive Sampling karena disesuaikan dengan tujuan penelitian sehingga diharapkan dapat menjawab permasalahan penelitian. Sampel dalam penelitian ini yaitu guru mata pelajaran sains (IPA) Biologi, Fisika, dan matematika pada MTsN Kota Salatiga dan MtsNU Kota Salatiga, 2) menentukan indikator tentang konsep dan strategi relasi sains dan agama dalam pembelajaran: indikator yang akan digunakan diadaptasi dari empat pendekatan hubungan sains dan agama yang dikembangkan oleh Ian G. Barbour (2005), 3) menentukan jenis instrumen yang digunakan yaitu berupa: angket, lembar observasi, dan wawancara. Penyusunan instrumen angket, lembar observasi, dan wawancara dilakukan dengan terlebih dahulu melakukan validasi isi dan konstruk oleh ahli.

Analisis data kualitatif digunakan berdasarkan hasil dari instrumen angket, lembar observasi, dan wawancara. Hasil yang diperoleh selanjutnya dianalisis secara deskriptif. Dari data-data yang diperoleh, direduksi kemudian dibuat polanya sehingga diperoleh gambaran konsep dan strategi relasi sains dan agama dalam pembelajaran menggunakan model Miles dan Huberman (Ghony dan Almanshur, 2012). 


\section{Relasi Sains dan Agama Menurut Ian G. Barbour}

Ilmu dan agama memiliki perbedaan cukup mendasar yang perlu dipertimbangkan sebelum mengetahui korelasi antara keduanya. Pertama, mind set dasarnya berbeda. Ilmu bersandar pada etos otonomi pemahaman. Singkatnya, sikap skeptis dan tak mudah percaya adalah kodrat seorang ilmuwan, sementara agama tentu saja kebalikannya. Sikap dasarnya adalah percaya dan kepasrahan pada kehendak otoritas lain, terutama otoritas Tuhan. Jadi, jika dalam dunia keilmuan ketidakpercayaan (sebelum terbukti) adalah sebuah keutamaan, dalam dunia keagamaan, keperccayaanlah yang menjadi keutamaan (Sugiharto dalam Bagir dkk, 2005).

Kedua, ilmu relatif lebih terbuka terhadap pandanganpandangan baru asalkan masuk akal dan ditunjang bukti faktual yang memadai. Agama agak sebaliknya, meski umumnya diyakini bahwa manusia wajib menggunakan akalnya untuk memahami wahyu atau kitab suci, dalam kenyataannya agama-agama cenderung sangat defensif terhadap pemahaman-pemahaman baru, bahkan agak tabu untuk memerkarakan dirinya sendiri. Tidaklah mengherankan jika dibandingkan dengan perkembangan ilmu yang sangat pesat, agama sering terasa tertinggal jauh. Bisa saja seorang ilmuwan yang sangat intelektual dalam keilmuannya, tetapi dalam hal keagamaan tetap kekanak-kanakan (Guiderdoni, 2004).

Ketiga, sebenarnya ranah utama wacana agama-agama adalah ranah misteri-misteri terdalam kehidupan beserta maknamakna pengalaman, yang sesungguhnya di luar wilayah atau di luar batas jangkauan ilmu-ilmu empirik. Bahasa yang digunakannya pun berbeda. Bahasa agama-agama lebih berupa bahasa mitos, penuh metafora ataupun retorika, sementara bahasa ilmu adalah bahasa faktual, lugas, dan literal.

Perbedaan dan persoalan tersbut memunculkan banyak wacana tentang integrasi ilmu dan agama oleh para ahli. Salah satu pendekatan integrasi sains dan agama dipopulerkan oleh Ian G. Barbour, Barbour sangat sadar akan adanya pertentangan diantaranya kedua dan berusaha untuk mencari kemitraan yang konstruktif antara keduanya. Barbour berusaha mencirikan integrasi secara umum dengan membedakannnya dari pendekatan konflik 
(sains dan agama mau tak mau beretentangan), atau independensi (bahwa keduanya seharusnya, atau bahkan selogisnya, jalan sendirisendiri) (Humaidi, 2015).

Menurut Barbour, hubungan sains dengan agama dibagi menjadi empat varian hubungan yaitu: konfilik, independensi, dialog, dan integrasi.

1. Konflik; dalam hubungan konflik, sains menegaskan eksistensi agama dan agama menegasikan sains. Masing-masing hanya mengakui keabsahan eksisitensi dirinya. Dalam hubungan ini menyatakan bahwa sains dan agama adalah bermusuhan/ bertentangan (Barbour 2005).

2. Independensi; dalam hubungan independensi, masing-masing mengakui keabsahan eksistensi yang lain dan menyatkana bahwa di antara sains dan agama tak ada irisan satu sama lainnya. Independensi menyatakan bahwa sains dan agama adalah dua domain yang independen yang dapat hidup bersama sepanjang mempertahankan jarak aman satu sama lain. Konflik dapat dihindarkan kalau ilmu pengetahuan dan agama tetap berada dalam ruang-ruang hidup manusia yang terpisah. Ilmu pengetahuan dan agama berurusan dengan ranah-ranah yang berbeda dan aspek realitas yang berbeda. Ilmu pengetahuan bertanya tentang bagaimana sesuatu bekerja dan mengandalkan data publik yang objektif. Agama bertanya tentang nilai-nilai dan kerangka makna yang lebih besar bagi hidup pribadi. Dalam pandangan ini, dua bentuk wacana tidaklah bersaingan karena mereka melayani fungsi-fungsi yang benar-benar berbeda. Dua jenis penyelidikan itu menawarkan pandangan-pandangan yang saling melengkapi tentang dunia, pandangan-pandangan yang tidak saling menyingkirkan satu sama lain. Pemisahan ruang (kompartementalisasi) semacam ini memang menghindarkan konflik, tetapi dengan risiko mencegak terbangunnya interaksi yang konstruktif (Barbour 2005).

3. Dialog; dalam hubungan dialog, diakui bahwa di antara sains dan agama terdapat kesamaan yang dapat didialogkan antara para ilmuwan dan agamawan, bahkan bisa saling mendukung. Dialog memotret hubungan yang lebih konstruktif anatara sains dan 
agama daripada pandangan konflik dan independensi. Namun, dialog tidak menawarkan kesatuan konseptual sebagaiana yang diajukan pendukung integrasi. Dialog mungkin muncul dengan mempertimbangkan pra-anggapan dalam upaya ilmiah, atau mengeksplorasi kesejajaran metode antara sains dan agama, atau menganalisiskan konsep dalam satu bidang dengan konsep dalam bidang lain. Dalam membandingkan sains dan agama, dialog menekankan kemiripan dalam praanggapan, metode, dan konsep. Sebaliknya independensi menekankan perbedaan yang ada (Barbour 2002).

4. Integrasi; beberapa orang mengupayakan suatu integrasi yang lebih sistematik antara ilmu pengetahuan dan agama. Kemitraan yang lebih sistematis dan ekstensif antara sains dan agama terjadi di kalangan yg mencari titik temu di antara keduanya. Barbour menyatakan adanya tiga varian integrasi, yaitu: Natural theology (teologi natural), theology of nature (teologi alam), dan sintesis sistematis.

Dalam natural tehology, dinyatakan bahwa argumen didasarkan pada sains semata. Adanya klaim bahwa eksistensi Tuhan dapat disimpulkan dari (atau didukung oleh) bukti tentang desain alam, yang tentangnya alam membuat kita semakin menyadarinya. Teologi mencari dukungan pada penemuan-penemuan ilmiah.

Dalam Theology of nature, sumber utama teologi terletak di luar sains, tetapi teori-teori ilmiah bisa berdampak kuat atas perumusan ulang doktrin-doktrin tertentu, terutama doktrin tentang penciptaan dan sifat dasar manusia. Pandangan teologis tentang alam justru harus diubah, disesuaikan dengan penemuan-penemuan sains yang mutakhir tentang alam. Dalam teologi alam, sains dan agama dipandang sebagai sumber ideide yang relatif independen, tetapi tumpang tindih dalam bidang minatnya.

Sedangkan dalam sintesis sistematis, sains ataupun agama memberikan kontribusi pada pengembangan metafisika inklusif (Barbour 2002).. Integrasi yang lebih sistematis dapat dilakukan jika sains dan agama memberikan kontribusi ke arah pandangandunia yang lebih koheren yang dielaborasi dalam kerangka 
metafisika yang komprehensif. Metafisika adalah pencarian seperangkat konsep umum yang dapat menafsirkan berbagai aspek realitas (secara terpadu) (Barbour 2005).

\section{Proses Pelaksanaan Pembelajaran dalam Kurikulum 2013}

Mata pelajaran adalah unit organisasi terkecil dari Kompetensi Dasar. Untuk kurikulum SMP/MTs, organisasi Kompetensi Dasar dilakukan dengan cara mempertimbangkan kesinambungan antarkelas dan keharmonisan antarmata pelajaran yang diikat dengan Kompetensi Inti. Berdasarkan pendekatan ini maka terjadi reorganisasi Kompetensi Dasar mata pelajaran sehingga Struktur Kurikulum SMP/MTs menjadi lebih sederhana karena jumlah mata pelajaran dan jumlah materi berkurang (Kemendikbud, 2014).

Substansi muatan lokal termasuk bahasa daerah diintegrasikan ke dalam mata pelajaran Seni Budaya. Substansi muatan lokal yang berkenaan dengan olahraga serta permainan daerah diintegrasikan ke dalam mata pelajaran Pendidikan Jasmani, Olahraga, dan Kesehatan. Sedangkan Prakarya merupakan mata pelajaran yang berdiri sendiri.

Penyelenggaraan pendidikan dasar dan menengah sebagaimana yang dinyatakan dalam Peraturan Pemerintah Nomor 17 Tahun 2010 tentang Pengelolaan dan Penyelenggaraan Pendidikan bertujuan membangun landasan bagi berkembangnya potensi peserta didik agar menjadi manusia yang:

1. beriman dan bertakwa kepada Tuhan Yang Maha Esa, berakhlak mulia, dan berkepribadian luhur;

2. berilmu, cakap, kritis, kreatif, dan inovatif;

3. sehat, mandiri, dan percaya diri; dan

4. toleran, peka sosial, demokratis, dan bertanggung jawab.

Kurikulum sebagaimana yang ditegaskan dalam Pasal 1 Ayat (19) Undang-undang Nomor 20 Tahun 2003 adalah seperangkat rencana dan pengaturan mengenai tujuan, isi, dan bahan pelajaran serta cara yang digunakan sebagai pedoman penyelenggaraan 
kegiatan pembelajaran untuk mencapai tujuan pendidikan tertentu. Pengembangan Kurikulum 2013 merupakan langkah lanjutan Pengembangan Kurikulum Berbasis Kompetensi yang telah dirintis pada tahun 2004 dan KTSP 2006 yang mencakup kompetensi sikap, pengetahuan, dan keterampilan secara terpadu.

Kurikulum merupakan salah satu unsur yang memberikan kontribusi untuk mewujudkan proses berkembangnya kualitas potensi peserta didik tersebut. Kurikulum 2013 dikembangkan berbasis pada kompetensi sangat diperlukan sebagai instrumen untuk mengarahkan peserta didik menjadi: (1) manusia berkualitas yang mampu dan proaktif menjawab tantangan zaman yang selalu berubah; (2) manusia terdidik yang beriman dan bertakwa kepada Tuhan Yang Maha Esa, berakhlak mulia, sehat, berilmu, cakap, kreatif, mandiri; dan (3) warga negara yang demokratis, bertanggung jawab (Kemendikbud, 2014).

Tujuan Pendidikan Nasional sebagaimana telah dirumuskan dalam Undang-Undang Nomor 20 Tahun 2003 adalah untuk berkembangnya potensi peserta didik agar menjadi manusia yang beriman dan bertakwa kepada Tuhan Yang Maha Esa, berakhlak mulia, sehat, berilmu, cakap, kreatif, mandiri, dan menjadi warga negara yang demokratis serta bertanggung jawab. Secara singkatnya, undang-undang tersebut berharap pendidikan dapat membuat peserta didik menjadi kompeten dalam bidangnya.Di mana kompeten tersebut, sejalan dengan tujuan pendidikan nasional yang telah disampaikan di atas, harus mencakup kompetensi dalam ranah sikap, pengetahuan, dan keterampilan sebagaimana dijelaskan dalam penjelasan pasal 35 undang-undang tersebut.

Sejalan dengan arahan undang-undang tersebut, telah pula ditetapkan visi pendidikan tahun 2025 yaitu menciptakan insan Indonesia yang cerdas dan kompetitif.Cerdas yang dimaksud di sini adalah cerdas komprehensif, yaitu cerdas spiritual dan cerdas sosial/emosional dalam ranah sikap, cerdas intelektual dalam ranah pengetahuan, serta cerdas kinestetis dalam ranah keterampilan.

Dengan demikian, Kurikulum 2013 dirancang dengan tujuan untuk mempersiapkan insan Indonesia supaya memiliki kemampuan hidup sebagai pribadi dan warga negara yang beriman, 
produktif, kreatif, inovatif, dan afektif serta mampu berkontribusi pada kehidupan bermasyarakat, berbangsa, bernegara dan peradaban dunia. Kurikulum adalah instrumen pendidikan untuk dapat membawa insan Indonesia memiliki kompetensi sikap, pengetahuan, dan keterampilan sehingga dapat menjadi pribadi dan warga negara yang produktif, kreatif, inovatif, dan afektif.

Kompetensi pada Kurikulum 2013 dirancang berikut ini.

1. Isi atau konten kurikulum yaitu kompetensi dinyatakan dalam bentuk Kompetensi Inti (KI) kelas dan dirinci lebih lanjut dalam Kompetensi Dasar (KD) mata pelajaran.

2. Kompetensi Inti (KI) merupakan gambaran secara kategorial mengenai kompetensi dalam aspek sikap, pengetahuan, dan keterampilan (kognitif dan psikomotor) yang harus dipelajari peserta didik untuk suatu jenjang sekolah, kelas dan mata pelajaran. Kompetensi Inti adalah kualitas yang harus dimiliki seorang peserta didik untuk setiap kelas melalui pembelajaran KD yang diorganisasikan dalam proses pembelajaran siswa aktif.

3. Kompetensi Dasar (KD) merupakan kompetensi yang dipelajari peserta didik untuk suatu tema untuk SD/MI, dan untuk mata pelajaran di kelas tertentu untuk SMP/MTS, SMA/MA, SMK/MAK.

4. Kompetensi Inti dan Kompetensi Dasar di jenjang pendidikan menengah diutamakan pada ranah sikap sedangkan pada jenjang pendidikan menengah pada kemampuan intelektual (kemampuan kognitif tinggi).

5. Kompetensi Inti menjadi unsur organisatoris (organizing elements) Kompetensi Dasar yaitu semua KD dan proses pembelajaran dikembangkan untuk mencapai kompetensi dalam Kompetensi Inti.

6. Kompetensi Dasar yang dikembangkan didasarkan pada prinsip akumulatif, saling memperkuat (reinforced) dan memperkaya (enriched) antarmata pelajaran dan jenjang pendidikan (organisasi horizontal dan vertikal).

7. Silabus dikembangkan sebagai rancangan belajar untuk satu tema (SD/MI) atau satu kelas dan satu mata pelajaran (SMP/ 
MTS, SMA/MA, SMK/MAK). Dalam silabus tercantum seluruh KD untuk tema atau mata pelajaran di kelas tersebut.

8. Rencana Pelaksanaan Pembelajaran dikembangkan dari setiap KD yang untuk mata pelajaran dan kelas tersebut.

Proses pembelajaran pada Kurikulum 2013 terdiri atas pembelajaran intrakurikuler dan pembelajaran ekstrakurikuler.

Prinsip-prinsip pembelajaran intrakurikuler sebagai berikut.

1. Proses pembelajaran intrakurikuler adalah proses pembelajaran yang berkenaan dengan mata pelajaran dalam struktur kurikulum dan dilakukan di kelas, sekolah, dan masyarakat.

2. Proses pembelajaran di SD/MI berdasarkan tema sedangkan di SMP/MTS, SMA/MA, dan SMK/MAK berdasarkan Rencana Pelaksanaan Pembelajaran yang dikembangkan guru.

3. Proses pembelajaran didasarkan atas prinsip pembelajaran siswa aktif untuk menguasai Kompetensi Dasar dan Kompetensi Inti pada tingkat yang memuaskan (excepted).

4. Proses pembelajaran dikembangkan atas dasar karakteristik konten kompetensi yaitu pengetahuan yang merupakan konten yang bersifat mastery dan diajarkan secara langsung (direct teaching), keterampilan kognitif dan psikomotorik adalah konten yang bersifat developmental yang dapat dilatih (trainable) dan diajarkan secara langsung (direct teaching), sedangkan sikap adalah konten developmental dan dikembangkan melalui proses pendidikan yang tidak langsung (indirect teaching).

5. Pembelajaran kompetensi untuk konten yang bersifat developmental dilaksanakan berkesinambungan antara satu pertemuan dengan pertemuan lainnya dan saling memperkuat antara satu mata pelajaran dengan mata pelajaran lainnya.

6. Proses pembelajaran tidak langsung (indirect) terjadi pada setiap kegiatan belajar yang terjadi di kelas, sekolah, rumah dan masyarakat. Proses pembelajaran tidak langsung bukan kurikulum tersembunyi (bidden curriculum) karena sikap yang dikembangkan dalam proses pembelajaran tidak langsung 
harus tercantum dalam silabus, dan Rencana Pelaksanaan Pembelajaran (RPP) yang dibuat guru.

7. Proses pembelajaran dikembangkan atas prinsip pembelajaran siswa aktif melalui kegiatan mengamati (melihat, membaca, mendengar, menyimak), menanya (lisan, tulis), menganalis (menghubungkan, menentukan keterkaitan, membangun cerita/ konsep), mengkomunikasi-kan (lisan, tulis, gambar, grafik, tabel, chart, dan lain-lain).

8. Pembelajaran remedial dilaksanakan untuk membantu peserta didik menguasai kompetensi yang masih kurang. Pembelajaran remedial dirancang dan dilaksanakan berdasarkan kelemahan yang ditemukan berdasarkan analisis hasil tes, ulangan, dan tugas setiap peserta didik. Pembelajaran remedial dirancang untuk individu, kelompok atau kelas sesuai dengan hasil analisis jawaban peserta didik.

9. Penilaian hasil belajar mencakup seluruh aspek kompetensi, bersifat formatif dan hasilnya segera diikuti dengan pembelajaran remedial untuk memastikan penguasaan kompetensi pada tingkat memuaskan.

Pembelajaran ekstrakurikuler adalah kegiatan yang dilakukan untuk aktivitas yang dirancang sebagai kegiatan di luar kegiatan pembelajaran terjadwal secara rutin setiap minggu. Kegiatan ekstrakurikuler terdiri atas kegiatan wajib dan pilihan. Pramuka adalah kegiatan ekstrakurikuler wajib. Kegiatan ekstrakurikuler wajib dinilai yang hasilnya digunakan sebagai unsur pendukung kegiatan intrakurikuler.

Pengembangan kurikulum didasarkan pada prinsip-prinsip berikut ini.

1. Kurikulum bukan hanya merupakan sekumpulan daftar mata pelajaran karena mata pelajaran hanya merupakan sumber materi pembelajaran untuk mencapai kompetensi.

2. Kurikulum didasarkan pada standar kompetensi lulusan yang ditetapkan untuk satu satuan pendidikan, jenjang pendidikan, dan program pendidikan. Sesuai dengan kebijakan pemerintah mengenai Wajib Belajar 12 Tahun maka Standar Kompetensi 
Lulusan yang menjadi dasar pengembangan kurikulum adalah kemampuan yang harus dimiliki peserta didik setelah mengikuti proses pendidikan selama 12 tahun.

3. Kurikulum didasarkan pada model kurikulum berbasis kompetensi. Model kurikulum berbasis kompetensi ditandai oleh pengembangan kompetensi berupa sikap, pengetahuan, keterampilan berpikir, dan keterampilan psikomotorik yang dikemas dalam berbagai mata pelajaran.

4. Kurikulum didasarkan atas prinsip bahwa setiap sikap, keterampilan, dan pengetahuan yang dirumuskan dalam kurikulum berbentuk Kompetensi Dasar dapat dipelajari dan dikuasai setiap peserta didik (mastery learning) sesuai dengan kaidah kurikulum berbasis kompetensi.

5. Kurikulum dikembangkan dengan memberikan kesempatan kepada peserta didik untuk mengembangkan perbedaan dalam kemampuan dan minat.

6. Kurikulum berpusat pada potensi, perkembangan, kebutuhan, dan kepentingan peserta didik dan lingkungannya. Kurikulum dikembangkan berdasarkan prinsip bahwa peserta didik berada pada posisi sentral dan aktif dalam belajar.

7. Kurikulum harus tanggap terhadap perkembangan ilmu pengetahuan, budaya, teknologi, dan seni.

8. Kurikulum harus relevan dengan kebutuhan kehidupan.

9. Kurikulum harus diarahkan kepada proses pengembangan, pembudayaan dan pemberdayaan peserta didik yang berlangsung sepanjang hayat.

10. Kurikulum didasarkan kepada kepentingan nasional dan kepentingan daerah.

11. Penilaian hasil belajar ditujukan untuk mengetahui dan memperbaiki pencapaian kompetensi. Instrumen penilaian hasil belajar adalah alat untuk mengetahui kekurangan yang dimiliki setiap peserta didik atau sekelompok peserta didik. Kekurangan tersebut harus segera diikuti dengan proses memperbaiki kekurangan dalam aspek hasil belajar yang dimiliki seorang atau sekelompok peserta didik. 
IPA dan IPS dikembangkan sebagai mata pelajaran integrative science dan integrative social studies, bukan sebagai pendidikan disiplin ilmu. Keduanya sebagai pendidikan berorientasi aplikatif, pengembangan kemampuan berpikir, kemampuan belajar, rasa ingin tahu, dan pengembangan sikap peduli dan bertanggung jawab terhadap lingkungan sosial dan alam. Disamping itu, tujuan pendidikan IPS menekankan pada pengetahuan tentang bangsanya, semangat kebangsaan, patriotisme, serta aktivitas masyarakat di bidang ekonomi dalam ruang atau space wilayah NKRI. IPA juga ditujukan untuk pengenalan lingkungan biologi dan alam sekitarnya, serta pengenalan berbagai keunggulan wilayah nusantara.

Kurikulum 2013 dalam rekonstruksi kompetensi mencakup: sikap, pengetahuan, dan keterampilan.

1. Kompetensi sikap mencakup sikap spiritual (KI-1) dan sikap sosial (KI-2).

a. Sikap spiritual (KI-1) untuk mencapai insan yang beriman dan bertaqwa kepada Tuhan Yang Maha Esa.

b. Sikap sosial (KI-2) untuk mencapai insan yang berakhlak mulia, sehat, mandiri, demokratis, bertanggung jawab.

2. Kompetensi pengetahuan (KI-3) untuk mencapai insan yang berilmu.

3. Kompetensi keterampilan (KI-4) untuk mencaai insan yang cakap dan kreatif.

Permendikbud Nomor 22 Tahun 2016 Tentang Standar Proses Pendidikan Dasar dan Menengah, menjelaskan bahwa pelaksanaan pembelajaran merupakan implementasi dari RPP, meliputi kegiatan pendahuluan, inti, dan penutup. wajib:

Kegiatan pendahuluan, dalam kegiatan pendahuluan, guru

1. menyiapkan peserta didik secara psikis dan fisik untuk mengikuti proses pembelajaran;

2. memberi motivasi belajar peserta didik secara kontekstual sesuai manfaat dan aplikasi materi ajar dalam kehidupan sehari-hari, 
dengan memberikan contoh dan perbandingan lokal, nasional dan internasional, serta disesuaikan dengan karakteristik dan jenjang peserta didik;

3. mengajukan pertanyaan-pertanyaan yang mengaitkan pengetahuan sebelumnya dengan materi yang akan dipelajari;

4. menjelaskan tujuan pembelajaran atau kompetensi dasar yang akan dicapai; dan

5. menyampaikan cakupan materi dan penjelasan uraian kegiatan sesuai silabus.

Kegiatan inti menggunakan model pembelajaran, metode pembelajaran, media pembelajaran, dan sumber belajar yang disesuaikan dengan karakteristik peserta didik dan mata pelajaran. Pemilihan pendekatan tematik dan /atau tematik terpadu dan/ atau saintifik dan/atau inkuiri dan penyingkapan (discovery) dan/ atau pembelajaran yang menghasilkan karya berbasis pemecahan masalah (project based learning) disesuaikan dengan karakteristik kompetensi dan jenjang pendidikan.

1. Sikap

Sesuai dengan karakteristik sikap, maka salah satu alternatif yang dipilih adalah proses afeksi mulai dari menerima, menjalankan, menghargai, menghayati, hingga mengamalkan. Seluruh aktivitas pembelajaran berorientasi pada tahapan kompetensi yang mendorong peserta didik untuk melakuan aktivitas tersebut.

2. Pengetahuan

Pengetahuan dimiliki melalui aktivitas mengetahui, memahami, menerapkan, menganalisis, mengevaluasi, hingga mencipta. Karakteritik aktivititas belajar dalam domain pengetahuan ini memiliki perbedaan dan kesamaan dengan aktivitas belajar dalam domain keterampilan. Untuk memperkuat pendekatan saintifik, tematik terpadu, dan tematik sangat disarankan untuk menerapkan belajar berbasis penyingkapan/penelitian (discovery/ inquiry learning). Untuk mendorong peserta didik menghasilkan karya kreatif dan kontekstual, baik individual maupun kelompok, disarankan yang menghasilkan karya berbasis pemecahan masalah (project based learning). 


\section{Keterampilan}

Keterampilan diperoleh melalui kegiatan mengamati, menanya, mencoba, menalar, menyaji, dan mencipta. Seluruh isi materi (topik dan sub topik) mata pelajaran yang diturunkan dari keterampilan harus mendorong peserta didik untuk melakukan proses pengamatan hingga penciptaan. Untuk mewujudkan keterampilan tersebut perlu melakukan pembelajaran yang menerapkan modus belajar berbasis penyingkapan/penelitian (discovery/inquiry learning) dan pembelajaran yang menghasilkan karya berbasis pemecahan masalah (project based learning).

Dalam kegiatan penutup, guru bersama peserta didik baik secara individual maupun kelompok melakukan refleksi untuk mengevaluasi:

1. seluruh rangkaian aktivitas pembelajaran dan hasil-hasil yang diperoleh untuk selanjutnya secara bersama menemukan manfaat langsung maupun tidak langsung dari hasil pembelajaran yang telah berlangsung;

2. memberikan umpan balik terhadap proses dan hasil pembelajaran;

3. melakukan kegiatan tindak lanjut dalam bentuk pemberian tugas, baik tugas individual maupun kelompok; dan

4. menginformasikan rencana kegiatan pembelajaran untuk pertemuan berikutnya.

Konsep Relasi Sains dan Agama dalam Pelaksanaan Pembelajaran di Madrasab

Aspek yang digunakan untuk mengungkap konsep integrasi dalam pembelajaran adalah konsep integrasi, tujuan pembelajaran, dan sumber acuan. Sedangkan komponen strategi penerapan integrasi dijabarkan melalui aspek kebijakan lembaga. Penggalian data konsep integrasi dalam pembelajaran, dilakukan melalui angket dan wawancara. Subjek dalam penelitian ini adalah guru IPA dan Matematika pada MTsN dan MTs NU Kota Salatiga. 
Data yang diperoleh tentang konsep integrasi keilmuan dalam pembelajaran adalah:

1. Konsep integrasi di MTs N Salatiga

Konsep integrasi yang dimiliki oleh guru MTs N Salatiga sudah pada tataran integrasi khususnya pada teologi natural baik pada aspek konsep integrasi, tujuan pembelajaran, maupun sumber acuan. Pendekatan teologi natural pada aspek konsep integrasi, diketahui bahwa guru sudah memahami bahwa kebenaran agama tidak akan bertentangan dengan temuan sains. Apabila temuan sains bertentangan dengan agama, maka kebenaran agama mutlak didahulukan.

Pendekatan teologi natural pada aspek tujuan pembelajaran dikemukakan bahwa guru memahami bahwa tujuan dari pembelajarans sains adalah membuktikan kebenaran agama bersifat mutlak dan temuan sains memperkuat kebenaran agama.

Sedangkan aspek sumber acuan diketahui bahwa guru mengungkapkan bahwa sains dan agama memiliki sumber yang berbeda. Kebenaran agama bersumber dari al-Qur'an. Sains bersumber dari fenomena alam. Tetapi fenomena alam tidak bertentanganan dengan kebenaran agama.

Berdasarkan aspek konsep, tujuan pembelajaran dan sumber acuan, secara konsep integrasi guru sudah memahami adanya integrasi sains dan agama. Integrasi yang lebih banyak tampak pada tataran teologi natural di mana temuan sains harus relevan dengan agama

\section{Konsep Integrasi di MTs NU Salatiga}

Konsep integrasi yang ditemukan pada MTs NU Salatiga adalah pada tataran pendekatan dialog secara umum. Pada aspek konsep integrasi diketahui bahwa konsep hubungan sains dan agama yang dimiliki oleh guru belum pada tataran integrasi. Guru masih sekedar memahami bahwa sains dan agama sama-sama membuktikan keesaan Tuhan.

Aspek tujuan pembelajaran pada tataran pendekatan dialog. Pada aspek ini guru masih memahami, bahwa tujuan pembelajaran yang dilakukan masih pada tataran dialogis, di mana mempelajari 
sains untuk membantu memecahkan kebuntuan sains dan sebaliknya (Maarif, 2015).

Begitu juga pada aspek sumber acuan, diketahui bahwa guru belum memahami seutuhnya tentang sumber acuan dalam rangka mengintegrasikan sains dan agama. Guru masih memahami bahwa sumber acuan agama adalah al-Qur'an, sedangkan sumber acuan sains berasal dari buku-buku dan sumber belajar lain (Muspiroh, 2014).

Berdasarkan aspek konsep, tujuan pembelajaran dan sumber acuan. Dari ketiga aspek tersebut dapat dipahami bahwa dalam tataran konsep guru masih belum bisa memahami tentang integrasi sains dan agama. Hubungan sains dan agama masih sekedar dianggap bahwa belajar sains dan agama untuk membuktikan keesaan Tuhan, untuk nantinya lebih dapat meningkatkan keimanan kepada Allah SWT. Tataran tersebut dalam pandangan Barbour (2005) dianggap masuk dalam pendekatan dialog.

\section{Strategi Penerapan Relasi Sains dan Agama dalam Pelaksanaan Pembelajaran di Madrasah}

Aspek yang digunakan untuk mengetahui strategi penerapan integrasi keilmuan dalam pembelajaran sains dan matematika adalah tentang kebijakan lembaga, lembaga yang dimaksud adalah dari Madrasah pada khususnya dan Kementerian Agama pada umumnya. Instrumen yang digunakan adalah angket dan wawancara.

Berdasarkan temuan dari hasil wawancara, angket dan lembar observasi diperoleh hasil bahwa, tataran pendekatan pada aspek kebijakan lembaga baik pada MTsN Salatiga maupun MTs NU Salatiga, diperoleh pada tataran pendekatan dialog. Hal tersebut dikarenakan kedua madrasah tersebut sama-sama berada di naungan Kementerian Agama, sehingga dari pihak madrasah sama-sama memliki kebijakan tentang belum adanya kebijakan dari lembaga mengenai hubungan sains dan agama. Sedangkan dari pihak guru, sebagian sudah memahami konsep dari hubungan sains dan agama. Beberapa guru juga merasa menganggap penting untuk 
mengenalkan tentang integrasi sains dan agama. Sehingga mereka mempunyai inisiatif tersendiri untuk menerapkan hal tersebut meskipun belum maksimal dan masih hanya sekedar pengenalan.

Penelitian ini berusaha mengungkap tentang hubungan sains dan agama dalam pembelajaran di MTsN Kota Salatiga dan MTs NU Kota Salatiga. Hubungan sains dan agama yang kami amati, diadaptasi dari teori Barbour (2005) yang membagi hubungan sains dan agama menjadi empat pendekatan yakni: Konflik, Dialog, Independensi, dan Integrasi. Keempat pendekatan tersebut kemudian digunakan untuk melihat konsep dan strategi relasi sains dan agama dalam pembelajaran di madrasah. Aspek yang digunakan adalah 1) kebijakan lembaga, dan 2) konsep. Hasil dari temuan yang kami dapatkan secara ringkas dapat dilihat dari tabel berikut:

\section{Tabel 1: Konsep dan Strategi Relasi Sains dan Agama Menurut Barbour (2005) dalam Pembelajaran di MTsN dan MTs NU Kota Salatiga}

\begin{tabular}{ccc}
\hline \multirow{2}{*}{ Komponen } & \multicolumn{2}{c}{ Pendekatan Hubungan Sains dan Agama } \\
& MTs N Salatiga & MTs NU Salatiga \\
\hline Konsep Integrasi & Integrasi (Teologi Natural) & Dialog \\
Strategi Penerapan & Dialog & Dialog \\
\hline
\end{tabular}

Berdasarkan data temuan tersebut, dapat dilihat bahwa pada MTs Negeri Salatiga, sudah nampak adanya integrasi sains dan agama pada tataran konsep relasi sains dan agama. Hal tersebut menunjukkan bahwa guru sudah memahami tentang adanya konsep integrasi sains dan agama dalam pelaksanaan pembelajaran. Sedangkan temuan yang didapatkan dari MTs NU Salatiga, dari kedua komponen menunjukkan dominasi pada pendekatan dialog. Artinya, dari madrasah tersebut belum nampak adanya pengembangan konsep relasi dan agama dalam pembelajaran. Hal tersebut dikarenakan kurangnya pemahaman dari guru tentang konsep relasi sains dan agama, dan belum adanya kebijakan dari lembaga. 
Melihat dari dua fenomena yang terjadi di kedua madrasah tersebut, seperti yang dikemukakan oleh Mahzar dalam (Bagir dkk, 2005) bahwa implementasi integrasi sains dan agama dalam suatu institusi harus meliputi empat implementasi, yaitu pada tataran konsepsional, institusional, operasional, dan arsitektural. Konsepsional artinya madrasah sebagai lembaga pendidikan harus mampu memahami, mengarahkan, dan mendidik siswanya menjadi insan kamil yang selain memahami sains juga memahami ilmu agama. Institusional artinya lembaga harus memiliki kebijakan yang tegas mengenai implementasi integrasi sains dan agama (Hasanah dan Zuhaida, 2018). Operasional yang artinya kurikulum yang harus memasukkan konsep-konsep fundamental ilmu agama beriringan dengan sains yang nantinya diterapkan dalam perangkat pembelajaran, materi ajar, serta pelaksanaan pembelajaran. Sedangkan tataran arsitektural, madrasah sebagai lembaga pendidikan juga selain memiliki ruangan-ruangan pengembangan bidang sains juga harus menghidupkan sarana-sarana ibadah seperti mushola dan masjid.

Berdasarkan implementasi integrasi sains dan agama yang dikemukakan oleh Mahzar (Bagir dkk, 2005) bahwa implementasi integrasi sains dan agama dari MTs N Salatiga baru pada tataran konsepsional. Sedangkan pada MTs NU Salatiga belum terlihat adanya integrasi sains dan agama.

\section{Simpulan}

Berdasarkan hasil penelitian, diperoleh simpulan tentang konsep dan strategi berbasis relasi sains dan agama dalam pembelajaran. Simpulan dari penelitian ini sebagai berikut: 1). Konsep relasi sains dan agama dalam pembelajaran di MTsN Kota Salatiga menunjukkan adanya tataran integrasi yaitu teologi natural. Sedangkan pada MTs NU Kota Salatiga menunjukkan bahwa relasi sains dan agama masih pada tataran dialog. 2). Strategi relasi sains dan agama dalam pembelajaran baik pada MTsN Kota Saltiga maupun MTs NU Kota Salatiga, menunjukkan bahwa relasi sains dan agama baru sampai pada tataran dialog. 


\section{Daftar Pustaka}

Bagir, Zainal Abidin. 2005. Integrasi Ilmu dan Agama: Interpretasi dan Aksi. Mizan Pustaka.

Barbour, Ian G. 2002. Juru bicara Tuhan antara sains dan agama. Pustaka Mizan.

. 2005. Menemukan Tuhan dalam Sains Kontemporer dan Agama. Bandung: Mizan Pustaka.

Bruner, J.S. 1960. The Process of Education. Harvard University Press Cambridge.

Fiteriani, Ida. 2014. Analisis Model Integrasi Ilmu dan Agama dalam Pelaksanaan Pendidikan di Sekolah Dasar Islam Bandar Lampung. Jurnal Terampil. Vol 2, Nomor 2, Januari 2014

Ghony, M.D. dan Almanshur, F. 2012. Metodologi Penelitian Kualitatif. Yogyakarta: Ar-Ruzz Media.

Guiderdoni, Bruno. 2004. Membaca Alam Membaca Ayat. Bandung: Mizan Pustaka

Hamzah, Faiz. 2015. Studi Pengembangan Modul Pembelajaran IPA Berbasis Integrasi Islam-Sains pada Pokok Bahasan Sistem Reproduksi Kelas IX Madrasah Tsanawiyah. Adabiyah Jurnal Pendidikan Islam. Volume I Nomor I September 2015

Hasanah, Nur. dan Zuhaida, A. 2018 Integrasi Keilmuan dalam Pembelajaran Sains dan Matematika di Madrasah. I. Salatiga: LP2M Press IAIN Salatiga.

Humaidi. 2015. Paradigma Sains Integratif Alfarabi. Jakarta: Sadra International Institute.

Kementerian Pendidikan dan Kebudayaan. Materi Pelatihan Implementasi Kurikulum 2013 Tahun 2014. Jakarta: Badan Pengembangan Sumber Daya Manusia Pendidikan dan Kebudayaan dan Penjaminan Mutu Pendidikan, 2014. Mahfudzoh, Siti. 2011. Pengaruh Integrasi Islam dan Sains Terhadap Matematika. Prosiding Seminar Matematika dan Pendidikan Matematika. Yogyakarta: FMIPA UNY 
Maarif, Samsul. 2015. Integrasi Matematika dan Islam dalam Pembelajaran Matematika. Jurnal Ilmiah Program Studi Matematika STKIP Siliwangi Bandung. Vol. 4, No. 2, September 2015

Marzano, R. J. 1985. Integrated instruction in learning-to-learn skills, thinking skills, traditional content and basic beliefs: A necessary unity (Tech. Rep.). Aurora, CO: Mid-continent Regional Educational Laboratory. (ERIC Document Reproduction Service No. ED 267906)

Muspiroh, Novianti. 2014. Integrasi Nilai-Nilai Islam Dalam Pembelajaran IPA Di Sekolah. Quality Jurnal Pendidikan Islam STAIN KUDUS. Vol. 2, No. 1, Tahun 2014.

Purwanto, Agus. 2015. Ayat-Ayat Semesta. Bandung: Mizan

Suryana. 2010. Metode Penelitian Metode Praktis Penelitian Kuantitatif dan Kualitatif. Bandung: UPI Bandung 